\title{
EXTENSÃO E POLÍTICAS PÚBLICAS: REFLEXÕES SOBRE O CAMPO JORNALÍSTICO, A PARTIR DE PIERRE BOURDIEU
}

\author{
NÚbia da CUnha Simão ${ }^{1}$ \\ https://orcid.org/0000-0002-8990-9012 \\ Pollyana Vieira de Andrade ${ }^{2}$ \\ https://orcid.org/0000-0002-8251-6558
}

\begin{abstract}
Resumo: A partir das leituras de Pierre Bourdieu propõe-se neste artigo estabelecer uma relação entre as características do campo jornalístico exploradas pelo teórico e a necessidade de Políticas Públicas e atuação dos programas de extensão. Observa-se a transmissão de informações que opta pela redundância de imagens e a fragmentação do conteúdo, apelo a violência e uso de termos vulgares com o objetivo de aumentar a audiência. Objetiva-se desta forma, perceber os limites que envolvem o jornalismo sensacionalista na televisão brasileira e pensar sobre a importância da formação pela extensão dos acadêmicos de jornalismo e publicidade e propaganda.
\end{abstract}

Palavras-chave: Extensão. Sensacionalismo. Violência.

Abstract: From the readings of Pierre Bourdieu it is proposed in this article to establish a relationship between the characteristics of the journalistic field explored by the theoretical and the need for Public Policies and the implementation of extension programs. It is observed that the transmission of information that opts for the redundancy of images and the

1 Mestra em Comunicação pela Faculdade de Informação e Comunicação na Universidade Federal de Goiás FIC- UFG, Especialista em Economia pela Universidade Estadual de Goiás, Jornalista graduada na Faculdade de Informação e Comunicação na Universidade Federal de Goiás FIC- UFG, Economista graduada pela Universidade Estadual de Goiás -UEG. Docente do curso de Publicidade e Propaganda da Pontifícia Universidade Católica de Goiás - PUC-GO. Professora Pesquisadora Pró-reitoria de Extensão e Pesquisa- PROPE- PUC-GO. Coordenadora do Programa de Extensão em Direitos Humanos- PUC-GO. Endereço para acessar este CV: http://lattes.cnpq. br/9575034173768476. E-mail: nubiasimao@gmail.com

2 Especialista em Computação pela Pontifícia Universidade Católica de Goiás, Graduada em Administração Pública pela Pontifícia Universidade Católica de Goiás, Graduada em Administração de Empresa pela Pontifícia Universidade Católica de Goiás. Integrante do Grupo de Estudos e Pesquisas em Educação a Distância - GEaD - UFG/FE. Atualmente é Assessora Técnica da Pró-Reitoria de Graduação da Pontifícia Universidade Católica de Goiás - PROGRAD-PUC-GO. Endereço para acessar este CV: http://lattes.cnpq.br/1880573642186081. E-mail: pollyanavieiradeandrade@gmail.com 
fragmentation of the content, appeals to violence and the use of vulgar terms in order to increase the audience. The aim is to understand the limits of sensational journalism in Brazilian television and to think about the importance of training by the extension of journalism scholars and advertising and marketing.

Key-words: Extension. Sensationalism. Violence.

Resumen: A partir de las lecturas de Pierre Bourdieu se propone en este artículo establecer una relación entre las características del campo periodístico explotadas por el teórico y la necesidad de Políticas Públicas y actuación de los programas de extensión. Se observa que transmisión de informaciones que opta por la redundancia de imágenes y la fragmentación del contenido, llaman a la violencia y uso de términos vulgares con el objetivo de aumentar la audiencia. Se trata de esta forma, percibir los límites que envuelven el periodismo sensacionalista en la televisión brasileña y pensar sobre la importancia de la formación por la extensión de los académicos de periodismo y publicidad y marketing..

Palabras clave: Extensión. Sensacionalismo. Violencia.

Submetido em: 16/12/2018

Aceito em: 21/12/2018.

\section{EPISTEMOLOGIA DE CAMPO EM BOURDIEU}

Para Bourdieu (1989) em seu livro Teoria da Prática a proposta é uma observação na qual a sociedade é uma soma de diversos universos independentes que são compostos interiormente por relações únicas, quase sempre dissimuladas por posições de poder ocupadas por indivíduos.

O autor defende uma concepção de campo como uma estrutura de relações objetivas, que, quando observadas, explicam as interações entre os indivíduos que compõe tal ambiente.

O campo é, portanto, um espaço de oposição de forças que levam a um jogo, a uma competição entre os agentes, que nada mais é do que uma disputa por posições de poder, percebidas a partir do capital social conferido a cada indivíduo no campo.

Nas palavras do autor "o campo se particulariza, pois, como um espaço onde se manifestam relações de poder, o que implica afirmar que ele se estrutura a partir da distribuição desigual de um quantum social que determina a posição que um agente específico ocupa em seu seio". (ORTIZ, 1983, p. 21) 


\section{DE QUAL CAMPO FALA-SE?}

A comunicação é uma habilidade humana e está diretamente ligada à necessidade de sobreviver. $\mathrm{O}$ ser humano sempre buscou referências sobre abrigo, alimentos e segurança o que ajudou na perpetuação da sua espécie ao longo dos anos. Foi o desenvolvimento da comunicação que tornou possível registrar e transmitir a herança cultural, imprescindível para o crescimento e desenvolvimento de tecnologias.

Para Bourdieu (1989) comunicar é trocar saberes. Tal troca ocorre em um contexto objetivo em que cada ente comunicador ocupa determinada posição de poder e está inserido em um espaço em que as relações foram previamente estabelecidas, tal locus é denominado campo. O autor sustenta a tese de que o ato de comunicar está diretamente relacionado a uma relação de forças entre os agentes do campo, em que diversos critérios influenciam o resultado, tais como nível econômico e reconhecimento político, determinado por outros entes do campo.

O desenvolvimento das habilidades de comunicação passa pelos movimentos físicos, por ruídos e chegam ao grafismo. A partir de então a voz humana é entoada pelo corpo humano e depois disso surge a veiculação no material de impressões, então por ondas de sonoras, por equipamentos radiofônicos, por aparelhos de televisão e atualmente na era da convergência, em plataformas de múltiplos suportes, pela rede mundial de computadores.

Assim até meados do século XVIII prevaleceu uma comunicação oral. A Revolução industrial provocou a mudança das pessoas para centros que mais tarde tornaram-se cidades. O trabalho externo às comunidades, a rigidez dos horários e locais dificultava a comunicação oral. O desenvolvimento industrial foi o movimento propulsor para a organização da veiculação de informações nos meios de comunicação.

No contexto da Revolução Industrial surgem então as primeiras produções humanas organizadas, os folhetins e mais tarde os jornais impressos. Aqui, o objetivo era suprir a falta de comunicação oral ocasionada com o crescimento das organizações humanas a partir do trabalho. Bourdieu (1989) explica que somente no século XIX, observa-se uma configuração que pode ser denominada como campo jornalístico. No momento em que a oferta de serviços de informações encontra concorrentes e disputa por audiência. O período marca a utilização da dramatização dos acontecimentos, conhecida atualmente por sensacionalismo. 
Bourdieu (1997) expõe o campo jornalístico como um espaço de disputa de forças entre os jornalistas reconhecidos por seus colegas, por seu desenvolvimento profissional de habilidades e competências e aqueles reconhecidos pelo público, que detêm maiores audiências. É a partir da atração do público em números que tais profissionais conseguem carrear anúncios e sustentar os veículos a que se ligam. O que explicita a extrema influência comercial que atinge o campo.

(O campo Jornalístico) é o lugar de uma oposição entre duas lógicas e dois princípios de legitimação: o reconhecimento pelos pares, concedido aos que reconhecem mais completamente os "valores" ou os princípios internos, e o reconhecimento pela maioria materializado no número de receitas, de leitores, de ouvintes ou de telespectadores, portanto, na cifra de venda (Best-sellers) e no lucro em dinheiro, sendo a sanção do plebiscito, nesse caso, inseparavelmente um veredito do mercado. (BOURDIEU, 1997, p. 105).

O campo jornalístico difere-se de outros, torna-se peculiar. Nos demais campos, o poder é conferido por representantes daquele campo, que possuem autoridade conferida pelos membros do grupo social. Já, no campo jornalístico devido a produção e circulação das informações, ser voltada para atingir o maior número de pessoas e atrair por conseguinte anúncios e assinaturas e preservar a remuneração dos jornalistas e a perpetuação dos veículos de comunicação. Portanto, a busca por público é inerente ao campo jornalístico, pressupondo uma lógica comercial sobre o mesmo.

A lógica comercial é determinada no campo jornalístico e reforça uma estrutura de dependência estrutural mercadológica, observando-se a busca dos membros do campo jornalístico pelo: o furo, o dead line (tempo de produção) e a produção de notícias baseada no que outras empresas da concorrência veicularam ou pretendem veicular.

Dar a notícia em primeira mão, ou seja, “o furo”. Bourdieu (1997, p. 107) explica desta forma: "denomina concorrência pela prioridade (...) que atrai e favorece os agentes dotados de disposições profissionais que tendem a colocar toda a prática jornalística sob o signo da velocidade (ou da precipitação) e da renovação permanente".

A velocidade de veiculação determina maior ou menor audiência. O público está sempre em busca de informações em tempo real, como se estivesse presenciando o fato. $\mathrm{O}$ furo pressupõe, portanto, a superficialidade, que para o autor é parte de um problema social. Bourdieu (1997, p. 107) explicita a 
ideia: "favorece uma espécie de amnésia permanente que é o avesso negativo da exaltação da novidade e também uma propensão a julgar os produtores e os produtos segundo a oposição do (novo) e do (ultrapassado). ”

O produto jornalístico tem um curto prazo de validade. Portanto, o que importa saber sobre um congestionamento devido a um desvio do trânsito devido a uma construção de um viaduto. Horas depois a informação seria inútil, pois, ao telespectador importa saber da obra para desvio no momento do engarrafamento, para justamente desviar. Cientes do serviço implícito nas informações os Jornalistas produzem a partir da premissa da velocidade em noticiar.

O prazo para fechamento de uma edição, o chamado fim da linha ou dead line pressupõe, portanto, o "fazer curto", "fazer simples" e o uso de fórmulas e técnicas que permitem o "vender bem" e rápido.

E os jornalistas são sem dúvida tanto mais propensos a adotar o "critério do índice de audiência" na produção ("fazer simples", "fazer curto" etc.) ou na avaliação dos produtos e mesmo dos produtores ("passa bem na televisão", "vende bem" etc.) quando ocupem uma posição mais elevada (diretores de emissora, redatores-chefe etc.) em um órgão mais diretamente dependente do mercado (uma emissora de televisão comercial por oposição a uma emissora cultural etc)". (BOURDIEU, 1997, p. 106).

A problemática está em noticiar a partir do que outros veículos. A engrenagem de venda de anúncios pressupõe crescente audiência, ou seja, coaduna com a lógica da produção de informações superficiais e muito parecidas entre os diversos meios de comunicação.

Um veículo pauta-se por três variáveis: a busca por um furo, pela notícia veiculada pela concorrência e ainda pelos índices de audiência alcançados nas suas emissões de conteúdos. Os membros do campo jornalístico em geral buscam "tirar proveito de seus fracassos evitando seus erros, e (a) contrapor-se a seus sucessos tentando tomar emprestados os supostos instrumentos de seus êxitos, temas de números especiais que os jornalistas se sentem obrigados a retomar, livros resenhados (...)" (BOURDIEU, 1997, p. 108). Ou seja, na grande mídia, circulam quase sempre temáticas similares, fontes e, até mesmo formas de abordar o tema muito parecidas.

Compreende-se assim que o problema mercadológico do campo jornalístico, está justamente em sua dependência, que é, portanto, estrutural, está no cerne do seu locus produtivo. O que se torna um problema social é que muitas pessoas mantém-se informadas pelos veículos de grande audiência e forma 
juízos de valor para participar da sociedade. É desta forma, que formulam-se pensamentos sobre a atuação do Estado e sobre a formulação de políticas sociais econômicas, por exemplo. A par disso, é possível compreender que a mídia empodera os agentes expostos em seus veículos, em detrimento de outros e assim, influi em outros campos também.

A análise do teórico permite então afirmar que o veículo mais frágil quanto à lógica de mercado entre todos os veículos de mediação é a televisão. Durante toda a sua existência ao coadunar sons e imagens a televisão sempre foi objeto de desejo entre os seres humanos. O que possibilitou ao longo dos anos o crescimento do seu alcance e poder simbólico, nunca antes registrados. Além do que, diferente do impresso, a televisão conta histórias a partir de imagens e relata acontecimentos o que a aproxima do receptor e facilita a compreensão da realidade. A TV isenta o receptor do esforço de ler, da atenção única, “distração provada pela junção dos sons às imagens junto ao cérebro humano, o que dispensa a concentração. Diversas pesquisas apontam que as pessoas fazem outras atividades, enquanto assistem televisão" (SIMÃO; TEMER, 2016).

\section{TELEVISÃO UM VEÍCULO PARA A CIDADANIA - ENTRE O SA- BER E AS SENSAÇÕES}

Para Marques de Melo (1984, p. 98) o direito à comunicação pode ser caracterizado como um dos principais instrumentos de acesso à cidadania.

É importante pontuar que a experiência humana na contemporaneidade encontra-se quase em sua totalidade mediada- ou seja- midiatizada. Os telejornais são espaços privilegiados nos quais a sociedade obtém informações, observa e compreende boa parte da dinâmica social e política (TEMER; SIMÃO, 2011).

Thompson (1998, p.182) expõe que "o desenvolvimento da mídia aumentou a capacidade dos indivíduos experimentarem, através da interação quase mediada, fenômenos que dificilmente poderiam encontrar na rotina ordinária de suas vidas. Conhece-se o monte Fuji sem nunca ter estado no Japão, vive-se tragédias naturais e guerras sentados no sofá".

A programação televisiva de notícias e reportagens impõe-se enquanto vitrines do social.

Expondo o que há de mais atrativo para assegurar sua contínua visualização. Para ampla parcela da população, tal espaço expõe o que é importante socialmente. Logo, o que não 
está exposto na vitrine midiática não merece atenção, não tem relevância. Surgem daí inúmeras consequências sociais, políticas, econômicas e culturais que colaboram para aumentar a deformidade social. (TEMER; SIMÃO, 2015).

Para Sodré (1992, p. 22), “a informação é um modo de organizar o espaço contemporâneo". E desta maneira o telejornal, pode ser percebido por muitas pessoas como espelho do social, ou seja, como fonte para constituição de elementos para discussões interpessoais e atuação na sociedade. Sodré (2002) destaca ainda que a objetividade característica do jornalismo do século XVIII e início do século XIX sofreu uma mutação a partir do surgimento da TV e da exploração da imagem, e atualmente a objetividade jornalística tornou-se para muitos jornalistas algo que se persegue sem intenção de alcançar.

Portanto, analisar o telejornalismo como um produto social neutro é, prematura percepção. Sobretudo, no Brasil. As emissoras de televisão no país poderiam facilmente ser consideradas modelos identificados como monopólio. A televisão no Brasil, tem sua propriedade atrelada a algumas famílias, cujos interesses pessoais e políticos, somados às características comerciais, já descritas, a partir de Bourdieu (1989), praticamente inviabilizam por si só as possibilidades de objetividade e neutralidade na comunicação.

Lima (2009) expõe que o sistema para concessão de emissoras de radiodifusão no Brasil corrobora para a formação dos monopólios. O sistema trusteeshipmodel, ou seja, a concessão é pública, porém de exploração privada tem caráter essencialmente comercial.

De fato, é necessário observar que há uma regulamentação para evitar irregularidades e garantir, entre outras coisas, a pluralidade de informação, porém faltam mecanismos sociais para a sua fiscalização. Lima (2009) expõe além, quando explica que a propriedade cruzada, ou seja, a previsão de uma única família ou grupo de empresários controlar emissoras de rádio e televisão, além de jornais e revistas seria, por si só, "um atentado à democracia, porque se este grupo tem vínculos com qualquer grupo político haverá a condução das informações de maneira a beneficiar essas elites" (TEMER; SIMÃO, 2015).

A vinculação dos grandes grupos de comunicação com lideranças políticas regionais e locais são alguns dos problemas que impedem a democratização da nossa comunicação. E sem ela não haverá diversidade e pluralidade de informações, vale dizer, opinião pública autônoma e, portanto, democracia plena. (LIMA, 2009, p. 93) 
Além do que é preciso salientar, a veiculação televisiva é onerosa em sua essência. Fazer televisão requer tecnologia para gerar, transmitir e arquivar. $\mathrm{O}$ alto nível de tecnologia exige contínuos investimentos financeiros. Além das peculiaridades de produção comerciais do produto notícia, ou seja, rotinas de produção extremamente atípicas como, por exemplo, veicular a informação em primeira mão, o tempo de produção do material, o deadline (horário limite para inclusão de material), etc.

Os limites da representação do real impostos ao telejornal começam pelo fato dele ser um produto vendido a dois públicos diferentes: um público genérico, que assiste o telejornal em suas casas ou locais diversos- o telespectador, e outro público diferenciado, que atua como financiador das produções televisivas - o anunciante. (MARCONDES FILHO, 2000, p. 116).

Portanto, analisar a relação entre público e anunciante é imprescindível para compreender o produto telejornal. Ou seja, a mídia veiculada pelo anunciante (uma das principais fontes de capital para as emissoras) busca a atenção do telespectador que assiste à televisão. Ao anunciar na televisão o anunciante compra a credibilidade conquistada muitas vezes, pelos telejornais da emissora que com seu trabalho somam valor ao produto ofertado. Em geral, nas grades de emissoras os horários nobres, ou seja, mais caros, são os intervalos justamente dos telejornais de maior audiência. Uma problemática circular.

\section{SOBRE POLÍTICAS PÚBLICAS}

De acordo com Canela (2007), o entendimento da construção das políticas públicas nos parece ainda engatinhar no jornalismo brasileiro. Há uma nítida separação entre a política partidária, legislativa e presidencial que ocupa, em geral, os cadernos de política dos jornais, onde a troca de ministros, as negociações com parlamentares, e as questões de interesse humano envolvendo "políticos profissionais" (ressaltando, aqui, um termo cunhado pelo sociólogo alemão Max Weber), têm espaço garantido, dado que todos são entendidos como elementos do que se pode chamar de política.

Segundo Canela (2007), nesse contexto, nos parece igualmente bem delimitada a ideia de política econômica, que também conta com um espaço garantido nos cadernos de economia. Sem embargo, as demais políticas públicas, não raro, acabam por não ser reconhecidas como pertencentes ao universo 
cognitivo e de significados da própria política. Ganham diferentes espaços nos jornais e são mais ou menos entendidas como políticas a depender do jornalista que é o encarregado da reportagem e das personagens que compõem o fato que está sendo noticiado. Para exemplificar esse contexto, Canela (2007) destaca que a violência só passa a ser entendida como uma questão de política pública à medida que sai dos cadernos policiais, sendo, portanto, coberta por repórteres diferenciados das redações, e se e quando as personagens centrais da notícia são membros dos executivos estaduais, municipais ou federais diretamente ocupados das políticas de segurança pública, ou na medida em que especialistas se dedicam ao tema, tratando-o como um fenômeno social, cultural e político, e até mesmo de saúde pública.

Entretanto, no que se refere ao desenvolvimento de uma política pública, Canela (2007) destaca diferentes fases que demandam o conhecimento de distintos níveis de informação (estatísticas, legislações, posições de atores diversos, melhores práticas). A mídia, portanto, é um potencial investigador e fornecedor destas informações, inclusive conferindo voz a fontes alternativas e contestadoras de dados oficiais. Papel este, em geral, pouco desempenhado.

Nesse sentido, acredita-se que toda política pública, em regimes democráticos, supõe que os atores por elas responsáveis devem demonstrar algum grau de responsabilidade, por assim dizer. Segundo Canela (2007), a imprensa, desde as discussões travadas pelos Federalistas para a constituição da democracia norte-americana, é entendida como uma das principais instituições de controle social dos governos eleitos e de outros atores componentes da vida pública que também devem ser "vigiados" (ONGs, empresas, etc.) Neste sentido, o acompanhamento não apenas do lançamento oficial de projetos, mas de sua continuidade, da idoneidade em sua execução e de seus resultados é (ou deveria ser) tarefa a ser conduzida com afinco pelos profissionais da notícia.

Contudo, Canela (2007) ressalta que a imprensa desempenha um papel central das democracias contemporâneas ao colaborar fortemente no rol de temas que serão prioritários para os espaços públicos de deliberação, ao ajudar na forma como esses temas serão conduzidos pelos distintos atores relevantes, ao fornecer informações contextualizadas para a reflexão ao redor desses temas e, por fim, ao se transformar em "defensores", por assim dizer, das ações dos atores responsáveis pela concepção, implementação e avaliação das políticas públicas.

Esse ano, de modo especial, há um estímulo maior à participação em Políticas Públicas, por meio da Conferência Nacional dos Bispos do Brasil - CNBB, 
ao apresentar o tema da Campanha da Fraternidade 2019: Fraternidade e Políticas Públicas, com o intuito de discutir essa temática em todo território nacional, além de fortalecer a cidadania e o bem comum.

Assim, de acordo com o Texto-Base da Campanha da Fraternidade - 2019, Políticas Públicas são ações e programas que são desenvolvidos pelo Estado para garantir e colocar em prática direitos que são previstos na Constituição Federal.

Segundo o mesmo Texto-Base da Campanha da Fraternidade - 2019, a Constituição Federal de 1988 possibilitou que fosse introduzido no panorama político brasileiro o que está afirmado no parágrafo único do art. $1^{\circ}$, ou seja, que "todo poder emana do povo, que o exerce por meio de representantes eleitos ou diretamente", de modo que foram criados mecanismos para o exercício de uma democracia direta, tais como o plebiscitos, referendos e projetos de lei de iniciativa popular. Possibilitou, ainda, que a gestão das políticas ligadas à Seguridade Social fosse descentralizada e com a participação direta da sociedade civil (art. 194, 198, 204, 206 e 227). A Constituição de 1988 possibilitou, portanto, a participação direta da sociedade na elaboração e implementação de Políticas Públicas através dos conselhos deliberativos, que foram propostos por leis complementares em quatro áreas: Criança e Adolescente, Saúde, Assistência Social e Educação.

Contudo, a Campanha da Fraternidade - 2019, propõe compreender melhor o papel e o sentido das Políticas Públicas, despertar a consciência e incentivar a participação de todo cidadão na construção dessas ações em âmbito nacional, estadual e municipal, bem como propor políticas que assegurem os direitos sociais aos mais frágeis e vulneráveis, trabalhando para que as Políticas Públicas eficazes de governo se consolidem como políticas de Estado. Assim, as Políticas Públicas podem ser relacionadas à educação, à saúde, aos direitos humanos, à assistência social, à economia, à zona rural, às mulheres, bem como à comunicação e tantos outros temas e direitos.

Por fim, o Texto-Base da Campanha da Fraternidade - 2019, ressalta que as Políticas Públicas, representam, portanto, soluções específicas para necessidades e problemas da sociedade, ela é a ação Estado, que busca garantir a segurança e a ordem, por meio da garantia dos direitos, e expressam em geral, os principais resultados oriundos da presença do Estado na economia e na sociedade brasileira. 


\section{A IMPORTÂNCIA DA FORMAÇÃO DE ESTUDANTES DE CO- MUNICAÇÃO NA EXTENSÃO}

Tendo em vista as peculiaridades do campo jornalístico em Bourdieu (1989) percebe-se a necessidade de formação dos acadêmicos de Jornalismo e Publicidade e Propaganda para uma atuação para a consolidação da cidadania e promoção dos Direitos Humanos.

Assim sendo, o Programa de Direitos Humanos da Pontifícia Universidade Católica de Goiás PDH/PUC-GO propõe em seu projeto pedagógico e suas ações a atuação.

$\mathrm{O} \mathrm{PDH}$ visa fortalecer os direitos e garantias fundamentais, e também objetiva a tutela constitucional nos direitos humanos, além de contribuir com o processo de formação crítica e reflexiva sobre o campo dos direitos e sua garantia, aspectos que perpassam a formação acadêmica dos estudantes envolvidos nas atividades do programa e da comunidade externa à universidade. Para isso, busca articular parcerias com entidades governamentais e não governamentais, com o escopo de fortalecer a consolidação dos direitos humanos em benefício da sociedade.

O Programa de Direitos Humanos da PUC Goiás se constitui a partir de uma gestão colegiada, composta por professores e estudantes. Todo trabalho, que tem como mote os princípios e concepções discutidas no presente Projeto Pedagógico, articulados em seus eixos de atuação, são definidas em reuniões entre seus membros, em consonância com a Coordenação de Extensão (CDEX) da PUC Goiás, bem como da Pró-Reitoria de Extensão e Apoio Estudantil (PROEX). O programa possui três frentes de atuação político-pedagógica e recebe voluntários de todos os cursos da universidade e pessoas da comunidade para participarem destas atividades. Quais sejam: Eixo Comunicação e Direitos Humanos, Eixo Educação e Direitos Humanos e Eixo Políticas Públicas e Direitos Humanos.

O Eixo Comunicação e Direitos Humanos tem como ementa: Comunicação e cidadania. Comunicação e direitos humanos. Comunicação e educação em direitos humanos. Comunicação e cidadania ativa.

Dentre as Ações desenvolvidas sob orientação das professoras do programa estão: Produção de material audiovisual (fotografia, vídeo e áudio) e utilização das mídias sociais como canal de promoção de direitos humanos. Trabalho realizado com a participação de acadêmicos da universidade por 
meio do programa de voluntariado, bem como com estagiários, uma parceria com a Escola de Comunicação da PUC Goiás.

O Eixo tem como objetivo articular ações e atividades de educação em direitos humanos por meio dos processos comunicativos. Elaborar e divulgar materiais em áudio, cartazes e vídeo de conteúdo em direitos humanos. Planejar, executar e divulgar campanhas educativas com viés em direitos humanos.

A proposta do Eixo justifica-se, pois, o acesso à informação também configura uma necessidade política e social. Comunicar-se é, ao mesmo tempo, uma forma de interagir socialmente e de interferir nas decisões sociais. Consequentemente, negar informações, dar informações falsas ou incompletas são formas de violação de direitos humanos, uma vez que nega ao indivíduo a condição necessária à sua participação no debate público.

Destaca-se ainda que a comunicação é um dos direitos fundamentais do homem, o que está expresso na Declaração Universal dos Direitos Humanos, de 1948, em seu artigo 19. Ali pode-se ler: “[...] todo o indivíduo tem o direito à liberdade de opinião e de expressão (...) e o de procurar, receber e difundir, sem consideração de fronteiras, informações e ideias por quais meios de expressão". O direito à comunicação perpassa, também, todas as gerações de cidadania, o que refletirá diretamente na sua efetivação. São ações permanentes do Eixo: Produção e divulgação de conteúdos nas mídias sociais; Produção de campanhas para as mídias sociais; Resgate e preservação de Memória.

O segundo Eixo de atuação do Programa é Educação e Direitos Humanos. Tem como ementa: Educação. Direitos Humanos. A relação entre direitos humanos e educação. Cultura da paz. Dignidade humana. Ações Previstas são: Discussões de temas relacionados aos direitos humanos por meio do Grupo de estudo. Produção de trabalhos para serem apresentados em eventos científicos de direitos humanos e áreas afins. Produção de pesquisa.

Objetivo do Eixo é a Educação em Direitos Humanos, que também tem destaque nas políticas do PDH da PUC Goiás, é uma das mediações fundamentais para o acesso ao legado histórico dos direitos humanos, bem como à sua historização atual e mesmo a universalização da dignidade humana através de ações afirmativas e práticas sociais efetivas, rumo a uma cultura dos Direitos Humanos como base para as necessárias transformações sociais no Brasil. Para tanto, é importante reconhecer a educação como um dos direitos humanos e a Educação em Direitos Humanos como parte fundamental do conjunto desses direitos. 
Como aponta Benevides (2007, p. 335).

há pouco mais de cem anos, vivíamos, nesta terra dita de Santa Cruz, no regime da Casa Grande e Senzala. Nossos antepassados defendiam a escravidão como 'natural' (...). Somos, portanto, herdeiros de um crime hediondo, causa principal da permanência, entre nós, de uma mentalidade que desconhece ou tende a dar um conteúdo pejorativo aos Direitos Humanos.

Benevides (2007, p. 347) não poupa ao defender a importância da difusão do conhecimento acerca dos direitos humanos, que já estão garantidos legalmente, mas isso não indica que necessariamente sejam compreendidos pelo cômputo geral da população nacional:

Uma vigorosa campanha de esclarecimento, nos meios de comunicação, do significado dos direitos humanos, associados à justiça social e à democracia, e um compromisso com a educação em direitos humanos, nas escolas, e em outros espaços públicos, desse já. (BENEVIDES, 2007, p. 347).

A educação em direitos humanos, à qual se propõe o PDH da PUC Goiás, de acordo com a autora, parte de três pontos fulcrais: em primeiro lugar, ela é permanente, contínua e deve ser abrangente. Em seguida, deve-se buscar uma mudança cultural. Por fim, deve atingir corações e mentes, pois não é somente transmissão de conhecimento. Acreditando nisso, o PDH realiza atividades permanentes de visibilidade dos direitos humanos e suas violações, como colóquios, debates, mesas redondas e rodas de conversa. O Eixo tem como ações permanentes: Grupo de Estudo; Roda de Conversa; Palestras, debates, encontros e seminários.

O terceiro Eixo de atuação político-pedagógica é Políticas Públicas em Direitos Humanos, e tem como ementa: Como componente de materialização da democracia, o PDH está ancorado na promoção dos direitos humanos, e, assim, em coerência com o PNDH3 e demais documentos legais que organiza as estratégias de operacionalização para uma participação direta e efetiva através das Relações Governamentais e com Segmentos Sociais da sociedade, dessa forma, requer o debate, a reflexão e a definição nas diversas políticas públicas e projetos sociais, desdobrando-se às responsabilidades dos sujeitos envolvidos. Assim, em conexão com o contexto socioeconômico e político contemporâneo, buscamos a construção coletiva dessas estratégias como objetivo deste eixo na luta e defesa permanente na consolidação e qualificação das relações estabelecidas. 
O objetivo do eixo é atuar na articulação e participação com Secretarias Federais, Estaduais e Municipais, bem como com os diversos Segmentos Sociais em direitos humanos, para o fortalecimento dos Direitos, contribuindo no aperfeiçoamento e demais competências relacionadas às atividades desenvolvidas em Políticas Públicas.

Esse Eixo tem como justificativa, reflexões sobre o texto base para a construção do Plano Municipal de Direitos Humanos de Goiânia, construído no ano de 2015, a partir da I Conferência Municipal de Direitos Humanos, onde inclusive o PDH teve efetiva participação e parceria com a Secretaria Municipal de Direitos Humanos, trouxe em um dos seus eixos a Interação Democrática por meio da Participação.

Essa concepção de interação democrática construída entre os diversos órgãos do Estado e a sociedade civil trouxe consigo resultados práticos em termos de políticas públicas e avanços na interlocução de setores do poder público com toda a diversidade social, cultural, étnica e regional que caracteriza os movimentos sociais em nosso País. Avançou-se fundamentalmente na compreensão de que os Direitos Humanos constituem condição para a prevalência da dignidade humana, e que devem ser promovidos e protegidos por meio de esforço conjunto do Estado e da sociedade civil.

E tem como ações permanentes o acompanhamento do Pop de Rua (Comitê Goiano Inter setorial da População em Situação de Rua); Participação em fóruns, conferências, conselhos e audiências públicas sobre direitos humanos; Realização de atividades em parceria com outros programas de extensão da PUC Goiás; Participação em comissões, fóruns e conselhos de direitos humanos; Participação e promoção de atividades científicas, como eventos e congressos.

Portanto, o PDH acredita que a participação é a maior materialização da democracia. É no diálogo e na integração que se dá o fortalecimento dos diversos mecanismos existentes na sociedade capazes de fortalecer as discussões e o monitoramento de Políticas Públicas voltadas aos direitos humanos no Brasil.

\section{ALGUMAS REFLEXÕES PARA PROSSEGUIR}

Observa-se "a intrusão de poderes da mídia, isto é, poderes econômicos mediatizados pela mídia, no universo da ciência mais pura" (BOURDIEU, 1997, p. 87). Tendo em vista a discussão sobre Políticas Públicas, é necessário que sejam estabelecidas legislações públicas para regular o veículo televisão. 
Ainda mais tendo em vista o problema da monetização no interior dos campos por meio da exposição nos telejornais, de certos membros como autoridades sobre determinado assunto é que, muitas vezes, estes agentes vão repetir lugares-comuns e preconceitos e longe de provocar mudanças no pensamento nas chamadas estruturas mentais do público, vão funcionar como uma espécie de "cola social" para que conflitos com origens sociais, políticas e econômicas possam ser tratados como fatos isolados, problemas individuais e conjunturais, somando para uma negligência das estruturas que necessitam ser repensadas pelo telespectador.

A nebulosidade gerada sobre as estruturas está relacionada a um uso superficial de conteúdo, "que consiste em se servir do conhecimento das leis do meio para tornar suas estratégias mais eficazes, outro, que se pode dizer clínico, que consiste em se servir do conhecimento das leis ou das tendências para combatê-las" (BOURDIEU, 1997, p. 87).

Ou seja, em lugar de se apropriar do que os diversos agentes têm para oferecer para a transformação do mundo, a mídia, especialmente a televisão opta por dar voz a agentes que vão colaborar para que a situação permaneça como está. Terríveis desigualdades sociais, por exemplo, uma escola de péssima qualidade, para se mencionar os problemas mais visíveis. Cegueira sobre a falta das estruturas, visível sobretudo, na cobertura dos acontecimentos localizados nos subúrbios das grandes cidades: Mesmo se a observação atenta da vida comum nesses subúrbios, com seus problemas quotidianos, for mais esclarecedora, a maioria dos jornalistas tendem a se concentrar na violência, a mais espetacular, e por isso, excepcional. (...) e a dar de modo misturado, como causas dessas desordens, as explicações colhidas pela imprensa, os abusos policiais, a desocupação dos jovens, a delinquência,(...) a falta de infraestrutura para esportes e lazer. (...) (CHAMPANHE in BOURDIEU, 2003, p. 69).

A baixa possibilidade de reflexão sobre os fatos do cotidiano serve para que boa parte da sociedade receba com naturalidade, por exemplo, fenômenos complexos, como a globalização, a adoção do modelo político econômico neoliberal, para dizer de um efeito da mídia em todo o mundo.

A falta de reflexão sobre as estruturas, coloca sob a responsabilidade do indivíduo problemas que estão postos socialmente. A fase denominada como "retorno do individualismo", funciona conformada pela televisão, como espécie de profecia auto-realizante que tende a destruir os fundamentos filosóficos do welfare state e, em particular, a noção de responsabilidade coletiva (nos acidentes de trabalho, na doença ou na miséria), essa conquista fundamental do pensamento social (e sociológico). 
Com o auxílio de telejornais em todo o mundo o retorno ao indivíduo é também o que permite "acusar a vítima”, única responsável por sua situação, e lhe pregar a "auto-ajuda", tudo isso sob o pretexto da necessidade incansavelmente reiterada de diminuir os encargos sociais do governo (BOURDIEU, 1998, p. 16).

Necessário recordar ainda, que o telejornal em sua busca por audiência, tende a buscar profissionais que atuam como verdadeiros animadores, com suas expressões faciais e gestuais atuam transformando fatos sociais em sensações individuais. Num movimento de baixa racionalidade e verdadeiro retorno à barbárie, ondas de risos, são substituídas pela raiva momentânea, o que por certo pouco vai provocar sobre as estruturas mentais, ou seja, pensamento.

A busca pelo sensacional, ou seja, por formas de mobilização puramente sentimentais e caricativas, ou igualmente passionais, porém agressivas e, próximas do linchamento simbólico reafirmando preconceitos e sem algum aprofundamento capaz de produzir algo novo, ou transformar o existente (BOURDIEU, 1997, p. 74). E se, atualmente, as políticas econômicas, por exemplo, são apresentadas mundialmente como necessidade social compartilhada, é necessário denunciar o trabalho simbólico forjado dia após dia com auxílio da televisão com ajuda de jornalistas e de agentes dos diversos campos. "Galileu dizia que o mundo natural está escrito em linguagem matemática. (...) Foi armando-se da matemática (e do poder da mídia) que o neoliberalismo se tornou a forma suprema da sociodicéia conservadora" (BOURDIEU, 1998, p. 50).

Desta maneira, observa-se atualmente, que grande parte dos fatos mostrados na televisão relativos, por exemplo, a situações que envolvem populações em situação de vulnerabilidade localizadas nas das periferias das grandes cidades são tratados pelos telejornais (que buscam as sensações para atrair público, sua grande maioria) como fenômenos isolados e de responsabilidade individual. Desconsidera-se, portanto, a ausência de políticas públicas e que tais fatos são também aos reflexos do modelo político econômico adotado. Há, para pensar um imenso sofrimento social sem precedentes, mostrado apenas como individual, de próprio de certo grupo social, pelas telinhas de milhares de televisores. "Seria necessário que todas as forças sociais críticas insistissem na incorporação aos cálculos econômicos dos custos sociais das decisões econômicas" (BOURDIEU, 1998, p. 55).

Desta forma, com este artigo objetivou-se sobretudo, desmistificar alguns dos mecanismos que conformam o campo jornalístico, "para desdramatizar a 
análise e para orientar racionalmente a ação" para usar as mesmas palavras de Pierre Bourdieu (1997, p. 78).

Após tal reflexão observa-se que o programa de Direitos possui três frentes de atuação político-pedagógica e recebe voluntários de todos os cursos da universidade e pessoas da comunidade para participarem destas atividades. Ou seja, após a leitura de Bourdieu (1989) e da nossa breve discussão sobre Políticas Públicas e a apresentação das frentes de atuação político-pedagógica do programa de Direitos Humanos é possível depreender a importância da participação de acadêmicos dos cursos de Jornalismo e Publicidade e Propaganda nas atividades do programa. Observa-se que entre os anos de 2014 e 2019 passaram pelo PDH 92 acadêmicos de jornalismo e 25 de Publicidade e Propaganda, e o programa trabalha junto às coordenações de curso para a ampliação da participação de tais acadêmicos, via estágio e voluntariado.

\section{REFERÊNCIAS}

BENEVIDES, Maria Victoria. Direitos Humanos: Desafios para o século XXI. In: SILVEIRA, Rosa Maria Godoy, et. al. (Orgs). Educação em Direitos Humanos: fundamentos teóricos-metodológicos. João Pessoa: Editora Universitária, 2007.

BOURDIEU, Pierre. A gênese dos conceitos de habitus e de campo. O poder simbólico. Rio de Janeiro: Bertrand Brasil, 1989. P. 59-73.

BOURDIEU, Pierre. Lições da aula. 2. ed. São Paulo: Ática, 2001.

BOURDIEU, Pierre. Esboço de uma teoria da prática. In: ORTIZ, Renato. (org.). Pierre Bourdieu: sociologia. São Paulo: Ática, 1983)

BOURDIEU, Pierre; PASSERON, Jean- Claude. A reprodução. Rio de Janeiro: Francisco Alves, 1975.

CANELA, G. Mídia e Políticas Públicas de Comunicação: uma análise empírica da imprensa brasileira. Pager apresentado no Anais do XXX Congresso Brasileiro de Ciências da Comunicação - Santos - 29 de agosto a 2 de setembro de 2007.

CNBB - Conferência Nacional dos Bispos do Brasil / Campanha da Fraternidade 2019: Texto-Base. Brasília: Edições CNBB, 2018.

ORTIZ, Renato (org). Pierre Bourdieu. São Paulo: Ática, 1983, in: SIMÃO, Núbia da Cunha. O campo jornalístico: sobre a televisão e sua influência. In: OLIVEIRA, João Ferreira de; PESSOA, Jadir de Morais (orgs.) Pesquisar com Bourdieu. Goiânia-GO: Cânone Editorial, 2013.

SIMAO, Núbia da Cunha; TEMER, Ana Carolina Pessoa Rocha. A construção da notícia na TV sob a lógica das rotinas produtivas: um espetáculo contra a cidadania. In: 
Congresso de Ciências da Comunicação da Região Centro Oeste, 2010, Goiânia. Anais do XII congresso de Ciências da Comunicação da Região Centro Oeste. São Paulo: Intercom, 2010.

SIMÃO, Núbia da Cunha. O campo jornalístico: sobre a televisão e sua influência. In: OLIVEIRA, João Ferreira de; PESSOA, Jadir de Morais (orgs.). Pesquisar com Bourdieu. Goiânia-GO: Cânone Editorial, 2013.

SODRÉ, Muniz; PAIVA, Raquel. O império do grotesco. Rio de Janeiro: MAUAD, 1992. SODRÉ, Muniz. O social irradiado! Violência urbana, neogrotesco e mídia. São Paulo: Cortez, 2002.

LIMA, Venício A. de. Mídia: Crise política e poder no Brasil. São Paulo: Editora Fundação Perseu Abramo, 2009. 